\title{
Salvador, Vitória da Conquista e Teófilo Otoni: cidades e falares diferentes? Uma análise discriminante da $\mathrm{F}_{0}$ Salvador, Vitória da Conquista e Teófilo Otoni: different citties and dialects? A discriminant analysis of the $F_{0}$
}

\begin{abstract}
Vera Pacheco* Marian Oliveira ${ }^{* *}$ Tássia da Silva Coelho***

RESUMO: Neste artigo, propomo-nos a avaliar a frequência fundamental $\left(\mathrm{F}_{0}\right)$ das vogais /a/, /i/ e /u/ em sílabas tônicas e pretônicas em falares de Vitória da Conquista, BA, Salvador, BA e Teófilo Otoni, MG. A escolha dessas cidades se deve ao contato próximo dos sujeitos dessas três cidade em decorrência da estreita relação sócioeconômica entre elas, apesar de estarem geograficamente distantes. Nossa hipótese é de que o falar de Vitória da Conquista pode sofrer influência dos outros falares. Para a realização deste trabalho, procedemos a mensuração da $\mathrm{F}_{0}$ tanto em sílaba tônica, quanto na sílaba pretônica, em três pontos da vogal: início, meio e fim. Em seguida, para a análise do agrupamento desses falares, realizamos a análise multivariada

ABSTRACT: In this article, we propose to evaluate the fundamental frequency $\left(\mathrm{F}_{0}\right)$ of the vowels $/ \mathrm{a} /, \mathrm{i} / \mathrm{and} / \mathrm{u} /$ of the speakers of Vitória da Conquista, Bahia, Salvador, BA and Teofilo Otoni, MG. We choose of these three cities because the contact between the natives due to narrow social and economic relationship between them, even though they are geographically distant. Our hypothesis is that Vitória Conquista dialect will suffer influence from the others dialects. For this work, we measure the vowel $\mathrm{F}_{0}$ of the stressed syllable and pre stressed syllable, in three points: first, middle and end. To analysis of grouping the dialects, we conducted discriminant multivariate analysis. The results show that Vitória da Conquista and Teofilo Otoni orm a group opposed to Salvador.
\end{abstract} discriminante. Os resultados mostram que os falares de Vitória da Conquista Teófilo Otoni formam um grupo que se opõe ao falar de Salvador.

PALAVRAS-CHAVE: Salvador. Vitória da Conquista. Teófilo Otoni. Análise acústica. Frequência fundamental.

KEYWORDS: Salvador. Vitória da Conquista. Teófilo Otoni. Acoustic Analysis. Fundamental Frequency.

\footnotetext{
* Doutora em Linguística. Docente do Departamento de Estudos Linguísticos e Literários da Universidade Estadual do Sudoeste da Bahia. Professora orientadora do Programa de Pós-Graduação em Linguística e do mestrado Profissional em Letras.

** Doutora em Linguística. Docente do Departamento de Estudos Linguísticos e Literários da Universidade Estadual do Sudoeste da Bahia. Professora orientadora do Programa de Pós-Graduação em Linguística e do mestrado Profissional em Letras.

${ }^{* * *}$ Mestre em Linguística.
} 


\section{Introdução}

Sabemos que quando se fala em diferenças dialetais, as diferentes realizações das vogais nas sílabas pretônicas é a que mais chama atenção. A realização das vogais médias abertas em sílaba pretônica é atribuída com frequência ao falar do Norte e do Nordeste. Essa divisão não é tão simples assim. Como lembram Lee e Oliveira (2003), podemos ter diferenças intra e interdialetal, ou seja, diferentes realizações vocálicas, em contextos específicos, dentro de um mesmo dialeto, e diferentes realizações entre dialetos diferentes.

Não podemos perder de vista, contudo, que a realização das vogais médias abertas em posição pretônica não é a única marca dialetal levantada pelos linguistas. $\mathrm{O}$ alteamento ou não dessas vogais nessa posição constitui uma forte marca dialetal como evidencia o trabalho de Bisol (1980).

Todavia, outras evidências fonética, além das vogais médias em sílaba pretônica, podem atuar na demarcação dialetal como as variações melódicas, como mostram vários trabalhos na literatura (CUNHA, 2000; COLOMARCO, 2005; LIRA, 2009; ZENDRON DA CUNHA, 2012; OLIVEIRA, 2014, entre outros). Os contornos melódicos dos diferentes tipos de orações do Português do Brasil (PB), declarativa, interrogativa, assertiva podem ser pistas importantes nas caracterizações dialetais. Aspectos prosódicos podem, portanto, variar de região para região.

Nos estudos prosódicos sobre variações dialetais, dentre os parâmetros acústicos avaliados, a frequência fundamental $\left(\mathrm{F}_{0}\right)$ tem-se destacado como um parâmetro importante (CUNHA, 2000; JACEWICZ; FOX, 2015).

É nesse contexto que nos propomos a avaliar o papel da $\mathrm{F}_{0}$ na delimitação do falar de três cidades importantes para os estados de Minas Gerais e Bahia, a saber: - Teófilo Otoni, localizada a nordeste de Minas Gerais -; Vitória da Conquista, no sudoeste da Bahia -; e Salvador, capital baiana, localizada mais ao norte do estado.

A escolha pela investigação desses três falares se deve ao contato próximo dos sujeitos dessas três cidade em decorrência da estreita relação sócio-econômica entre elas, apesar de essas cidades estarem geograficamente distantes. Vitória da Conquista, uma das cidades mais importantes do Sudoeste da Bahia, mantem traços estreitos tanto com Teófilo Otoni quanto com Salvador. Por ser considerada a "capital" do sudoeste baiano e possuir melhores condições de ensino, de assistência médica e maiores oportunidade de emprego, a cidade atrai cidadãos de outras cidades mineiras e baianas, principalmente de Teófilo Otoni, cujos moradores querem ir 
para uma cidade grande atrás de melhores condições de vida; e Salvador, pois os soteropolitanos buscam sair da loucura de uma capital e ir para uma cidade do interior mais tranquila, mas sem perder de vista uma infraestrura satisfatória. Além disso, muitos conquistenses passam parte de sua vida em Salvador e voltam para a cidade depois de um certo tempo.

É nesse cenário de um contato direto e muito próximo entre os falantes dessas três cidades que nos propomos a avaliar a $\mathrm{F}_{0}$, parâmetro acústico importante na caracterização dialetal, em sílabas tônica e pretônica nucleadas por /a/, /i/ e /u/.

Analisaremos a $\mathrm{F}_{0}$ tanto em sílaba tônica quanto pretônica porque padrões prosódicos dessas sílabas podem diferir entre os dialetos (CUNHA, 2000), bem como analisaremos essas sílabas nucleadas pelas vogais /a/, /i/ e /u/, pelo fato de essas três vogais, nos dialetos investigados, não estarem, a princípio, sujeitas a processos fonológicos que mudem a qualidade vocálica como se observa com as vogais médias que podem sofrer abaixamento, alteamento ou harmonia vocálica.

A pergunta que norteia esse trabalho é: o contato direto entre Teófilo Otoni e Vitória da Conquista e Vitória da Conquista e Salvador pode trazer consequências para o padrão de $\mathrm{F}_{0}$ do falar dos sujeitos nativos dessas três regiões? Em outras palavras, a $\mathrm{F}_{0}$ pode revelar, de alguma forma, a relação entre essas cidades?

Nosso objetivo é investigar a $\mathrm{F}_{0}$ das vogais /a/, /i/ e /u/ em sílabas tônica e pretônica de falantes naturais de Teófilo Otoni, Vitória da Conquista e Salvador. Assim objetivamos avaliar em que medida esses falares estão correlacionados entre si no que se refere à $\mathrm{F}_{0}$.

Nossa hipótese é que o padrão de $\mathrm{F}_{0}$ dos falantes de Vitória da Conquista seja intermediário entre o padrão de $\mathrm{F}_{0}$ dos falantes de Téofilo Otoni e Salvador, pois Vitória da Conquista recebe cidadão dessas das duas cidades.

Não há registro na literatura, até onde sabemos, de uma análise discriminante do padrão da $\mathrm{F}_{0}$, como a que se propõe aqui, na compreensão da configuração dialetal do Brasil. Os resultados aqui obtidos se somarão aos já encontrados na literatura e poderão contribuir na constituição do Atlas Prosódico de PB.

\section{Para além das vogais médias abertas em sílabas pretônicas: variação entoacional, $F_{0}$ e caracterização dialetal a partir das vogais /a,i,u/}

A realização das vogais médias abertas em sílaba pretônica é uma caracterização dos diferentes falares do PB há tempos já documentada na literatura. Nascentes, em 1953, 
considerou a ocorrência ou ausência dessas vogais em posição pretônica em determinadas regiões do país como critério para a sua proposta de divisão de seis subfalares ${ }^{1}$ em dois grandes grupos, o dos falares do Norte e o dos falares do Centro-Sul.

A divisão entre os falares, contudo, não é tão simples assim, pois, podemos ter variações das vogais pretônicas intra e inter dialetos (LEE; OLIVEIRA 2003). Além disso, nessa mesma posição silábica, processos de alteamento e harmonia vocálica podem ocorrer tanto nos falares da região norte (NINA, 1991; CRUZ ET AL. 2008, entre outros) e nordeste (MOTA, 1979; BORTONI, ET AL. 1991,VOGELY; HORA, 2013, entre outros) quanto nas regiões sul (BISOL, 1988; KAILER, 2012 entre outros) e sudeste (VIEGAS, 1987, CELIA, 2004, entre outros).

Apesar de a realização das vogais médias em sílaba tônica ser bastante variável entre os falares do PB, não podemos negar, todavia, que a ocorrêneía das vogais médias abertas na sílaba pretônica é um marcador dialetal utilizado com frequência pelos brasileiros no reconhecimento de falantes nordestinos, especialmente.

A presença ou não das vogais médias abertas em sílaba tônica não é o único delimitador dialetal. Variações nos padrões acústicos de sílabas pretônica e tônica, nos contornos entoacionais de assertivas e interrogativas, por exemplo, podem ocorrer nos diferentes dialetos do $\mathrm{PB}$, como registram os trabalhos realizados no âmbito do projeto $\mathrm{ALiB}^{2}$ e do projeto Amper ${ }^{3}$, além de outros estudos realizados fora do escopo desses dois projetos. Assim retomando as considerações de Cunha (2000, p. 185), "se os falares se distinguem prosodicamente e essa diferença é perceptível e descritível empiricamente por um leigo é porque, de fato, as diferenças existem e são passíveis de um estudo científico"; temos, portando, variações dialetais marcadas prosodicamente.

Essas variações dialetais prosodicamente marcadas podem ser atestadas na avaliação da configuração dos padrões acústicos de $\mathrm{F}_{0}$, intensidade e duração de sílabas tônicas e pretônicas

\footnotetext{
${ }^{1}$ Os termos "falares" e "dialetos" têm o mesmo significado: designam a realização variável de uma língua em função de fatores geográficos. Neste trabalho, optamos por usar os termos que as fontes consultadas utilizam.

${ }^{2}$ O Projeto ALiB (Atlas Linguístico do Brasil), coordenado pelas pesquisadoras Jacyra Mota e Suzana Cardoso, "tem como meta a realização de um atlas geral do Brasil no que diz respeito à lingua portuguesa" (CARDOSO; MOTA, 2007, p. 146) e agrega pesquisadores de diversas regiões do Brasil.

${ }^{3}$ O projeto Amper (Atlas Multimédia Prosódico do Espaço Românico), coordenado por Michel Contini e JeanPierri Lai, tem como principal objetivo o estudo da organização prosódica das variedades faladas no espaço dialectal românico. O projeto é sediado na Universidade de Grenoble Alpes, França, e conta com a participação de diversas universidades europeias e sul-americanas, inclusive universidades brasileiras (http://pfonetica.web.ua.pt/AMPER-POR.htm\#2) < acesso: 10/05/2016>.
} 
na caracterização dos falares de Recife, Salvador, Rio de Janeiro, São Paulo e Porto Alegre. Assim temos, de um lado, as cidades nordestinas Recife e Salvador que apresentam falas com pouca diferença entre os parâmetros acústicos das sílabas pretônicas e tônicas; e Porto Alegre de outro, cujo falar de seus nativos apresenta maiores valores da $\mathrm{F}_{0}$, intensidade e duração na sílaba tônica. Entre esses dois falares podemos encontrar São Paulo e Rio de Janeiro, cidades da região sudeste, cujos falares se caracterizam pelas sílabas tônicas e pretônicas com padrões acústicos que ora se assemelham àqueles dos falares nordestinos; ora aos da cidade gaúcha (CUNHA, 2000).

Ao avaliar o padrão melódico das interrogativas total para o nordeste, Lira (2009) apresenta basicamente dois padrões entoacionais, com marcas diferenciadoras no final do enunciado sobre a tônica ou a pós-tônica: 1) tônica final alta, seguida de pós-tônica (s) baixa (s) predominante em João Pessoa e Fortaleza e; 2) tônica final baixa, seguida de pós-tônica alta, predominante em Recife, Salvador e São Luis.

O padrão encontrado em João Pessoa e Fortaleza o é também para os falantes da ilha de Mosqueiro, Pará, apesar da não proximidade entre essas regiões, como ressalta Guimarães (2013).

O contorno melódico das interrogativas totais pode também variar entre os falares de alguns estados das regiões nordeste, sudeste e sul. De acordo com Silva e Cunha (2011), Rio de Janeiro, cidade carioca, da região sudeste, e Florianópolis, da região sul, têm, nesse tipo de sentença, seus falares caracterizados pelo contorno circunflexo (ascendente-descendente) no final dos enunciados, ao passo que Recife, cidade da região nordeste, apresenta contorno ascendente.

A semelhança no padrão da interrogativa total de Florianópolis e Rio de Janeiro, conforme dados de Silva e Cunha (2011), não é encontrada ao se comparar o alinhamento de $\mathrm{F}_{0}$ entre os falares de Florianópolis e Petrópolis, outra cidade do estado do Rio de Janeiro. De acordo com Seara e Rebollo-Couto (2011), na fala florianopolitana ocorre preferencialmente um alinhamento de $\mathrm{F}_{0}$ centralizado ou tardio, ao passo que na fala petropolitana ocorre um alinhamento antecipado.

Diferenças dialetais na realização das declarativas têm-se mostrado menos frequentes do que as diferenças encontradas nas interrogativas. Diferença na realização das declarativas foi encontrada em Seara e Rebollo-Couto (2011) também na comparação entre o falar de Florianópolis e Petrópolis. As declarativas nesses dois falares diferem entre si basicamente pela 
duração. De acordo com essas autoras, o dialeto fluminense se caracteriza por apresentar maior duração silábica se comparado ao falar dos catarinenses.

As pesquisas sobre caracterização e comparação de padrões prosódicos de diversas cidades de diferentes estados e regiões brasileiros evidenciam nitidamente que esse aspecto linguístico pode diferir dialeto. Mas esse mesmo aspecto linguístico pode diferenciar falares de cidades pertencentes a um mesmo estado e geograficamente próximas, como mostra o estudo de Sosa, Nunes e Seara (2013), ao investigar a fala de sujeitos naturais de três cidades catarinenses: Florianópolis, Blumenau e Lages. Os falantes de Lages apresentam tom ascendente-descendente na região nuclear e os falantes de Blumenau apresentam diferenças tonais na região pré-nuclear.

Os trabalhos que avaliam as diferenças nos padrões prosódicos entre os dialetos brasileiros deixam evidentes que dentre os parâmetros acústicos comumente envolvidos nas variações melódicas, $\mathrm{F}_{0}$, duração, intensidade, a $\mathrm{F}_{0}$ é aquele que mais se destaca na discriminação dialetal.

A $\mathrm{F}_{0}$ como um marcador dialetal parece não estar associada às variações melódicas, exclusivamente, mas igualmente associada à característica intrínseca das vogais, a $\mathrm{F}_{0}$ intrínseca, como demonstram Jacewicz e Fox (2015)

Apesar do consenso entre os pesquisadores de que a $\mathrm{F}_{0}$ intrínseca, ou pitch intrínseco, como chamam Ohala e Eukel (1987), das vogais ser uma consequência automática da articulação (CRANDAL, 1925, PETERSON; BARNEY, 1952; LEHISTE; PETERSON, 1961 apud OHALA; EUKEL, 1987), e, por isso, ser universal entre as línguas do mundo (WALEN;LEVITT,1995) ${ }^{4}$, o trabalho experimental realizado por como Jacewicz e Fox (2015) mostra que a $F_{0}$ intrínseca pode, sim, variar em contextos específicos entre os dialetos.

Jacewicz e Fox (2015) mostram experimentalmente que o valor da $F_{0}$ intrínseca das vogais /I , e , e, æ, aI / tende a altera-se em função da região de origem do falante. A pesquisa dos autores considerou três regiões diferentes dos Estados Unidos: Carolina do Norte; Ohio Central e Wisconsin, falantes do sul, da região central e do norte, respectivamente.

De acordo com os autores, $\mathrm{a} \mathrm{F}_{0}$ das vogais realizadas por falantes da Carolina do Norte segue um padrão típico da $\mathrm{F}_{0}$ das vogais realizadas por falantes de línguas tonais. Segundo os autores, a alteração da $\mathrm{F}_{0}$ intrínseca é observada em contextos prosódicos proeminentes, tais

\footnotetext{
${ }^{4}$ Vogais altas tendem a ter o valor da $\mathrm{F}_{0}$ intrínseca mais alta do que o das vogais baixas (OHALA; EUKEL, 1987).
} 
como foco da sentença. Para eles esse resultado reflete uma utilização diferenciada de produção da $\mathrm{F}_{0}$ pelas comunidades de fala. Os autores, contudo, não apresentam uma hipótese que possa explicar essa relação. Afirmam somente que a $\mathrm{F}_{0}$ intrínseca pode ser controlada pelo falante, não sendo somente uma contingência articulatória. Na visão dos autores, a alteração deliberada da $\mathrm{F}_{0}$ seria uma forma de aumentar a percepção da identidade social.

De fato o reconhecimento de uma língua ou de uma variedade linguística pode se dar somente a partir de informações prosódicas, especialmente pela variação de $\mathrm{F}_{0}$, segundo análise experimental realizada por Peres (2011), com base nos pressupostos de Atkinson (1968), Bonte (1975), Maidment (1976); Ohala e Gilbert (1978) e Bezooijen e Goss (1999)

Em condições experimentais de preservação prosódica dos estímulos, Peres (2011) encontrou aumento no reconhecimento de três variedades do Português do Brasil (Pelotas, (RS); São Paulo (bairro da Mooca) e Senador Pompeu (CE), por sujeitos naturais dessas regiões, em comparação com os estímulos que continham manipulações Segmentais e de $\mathrm{F}_{0}$. Diante desse resultado, o autor afirma que a $\mathrm{F}_{0}$ pode ser a responsável pelo reconhecimento, por parte dos sujeitos, de variedades linguísticas, isso porque a análise de produção feita por ele evidenciou pistas relevantes nas características desse parâmetro.

O trabalho de Peres (2011) evidencia que a percepção da fala não opera sem considerar questões de ordens dialetais. Assim, as variações dialetais devem ser contempladas nas investigações sobre a percepção da fala, bem como não pode ser negligenciada nas propostas de modelos para a percepção da fala (PISONI; REMEZ, 2005).

Diante das questões aqui apresentadas, podemos afirmar que a $F_{0}$ é um parâmetro acústico robusto na caracterização dialetal, em termos de produção, bem como o é no reconhecimento de um dialeto pelo ouvinte. Nesse cenário da eficácia da $\mathrm{F}_{0}$ na demarcação dialetal e considerando a relação entre os sujeitos naturais de Vitória da Conquista, Teófilo Otoni e Salvador, buscamos investigar a relação entre esses três falares de três regiões importantes para os estados de Minas Gerais e Salvador.

\section{Metodologia}

Buscando responder à pergunta posta neste trabalho, a saber: a ligação dos falantes naturais de Vitória da Conquista, Teófilo Otoni e Salvador decorrente da relação sócioeconômica dessas cidades pode trazer consequências para o padrão de $\mathrm{F}_{0}$ do falar dos sujeitos nativos dessas três regiões? e com vistas a alcançar os objetivos aqui propostos quais sejam: a) 
investigar a $\mathrm{F}_{0}$ das vogais /a/, /i/ e /u/ em sílabas tônica e pretônica dos falares de Teófilo Otoni, Vitória da Conquista e Salvador; e b) avaliar em que medida esses falares estão correlacionados entre si no que se refere à $\mathrm{F}_{0}$, a metodologia utilizada nesta pesquisa foi como se segue abaixo.

\subsection{As cidades}

O foco de nossa pesquisa foram três cidades diferentes: Vitória da Conquista, Teófilo Otoni e Salvador.

Vitória da Conquista, terceira maior cidade do interior do estado da Bahia, localiza-se no planalto da Conquista, região Sudoeste do estado, da qual é considerada a capital. Conforme estimativa do Instituto de Geografia e Estatística (IBGE) de 2014, a cidade possui 340 mil habitantes e é a capital regional de uma área que abrange oitenta municípios da Bahia e dezesseis do norte de Minas Gerais.

Salvador é a capital do estado da Bahia, estado localizado na Região Nordeste do país. A população soteropolitana é de mais de 2,9 milhões de habitantes, segundo estimativa do IBGE de 2014, e é o município mais populoso do Nordeste e o terceiro do Brasil. Salvador dista 519 km de Vitória da Conquista.

Teófilo Otoni, município do interior do estado de Minas Gerais, Região Sudeste do país, dista $389 \mathrm{~km}$ de Vitória da Conquista. Pertence à Mesorregião do Vale do Mucuri e Microrregião de Teófilo Otoni e localiza-se a Nordeste da capital do estado, Belo Horizonte, distando desta cerca de $450 \mathrm{~km}$. Sua população foi estimada pelo IBGE, em 2014, em 140 mil habitantes, sendo então o $18^{\circ}$ mais populoso do estado.

A motivação para a escolha dessas cidades foi estreito contato entre os cidadãos dessas três cidades decorrente da relação sócio-econômica que elas possuem. Vitória da Conquista é ao mesmo tempo desvinculada sócio-economicamente da capital Salvador, mas mantem contato com a mesma, graças ao fluxo de conquistenses indo e voltando para a capital para resolver demandas políticas e burocráticas. Mantém igualmente estreito laço com Teófilo Otoni, apesar de ser uma cidade de outro estado, de outra região brasileira, sendo possível encontrar morando em Vitória da Conquista, muitos teófilo-otonenses, graças a importância sócio-ecônomica de Vitória da Conquista para as cidades do norte de Minas. 


\subsection{Sujeitos da pesquisa}

Participaram dessas pesquisa seis sujeitos, um homem e uma mulher de cada uma das cidades, todos com idades entre 25 e 40 anos, naturais e residentes ao longo de toda suas vidas desses locais, com nível superior concluído ou em andamento.

\subsection{Montagem do corpus da pesquisa}

O corpus desta pesquisa foi montado com palavras reais e logatomas dissílabos que obedeceram à estrutura $\mathrm{CV}$.'CV, em que $\mathrm{C}$ é consoante e $\mathrm{V}$ vogal, nas quais a posição $\mathrm{C}$ foi ocupada por obstruintes sonoras e soantes, visto que as desvozeadas poderiam espraiar o desvozeamento para as vogais e desvozeá-las, e V pelas vogais altas/i/e/u/e a yogal baixa/a/. Antes da vogal /i/, foram inseridas consoantes [+ anteriores], por estarem na mesma zona de articulação, com a finalidade de atenuar processos fonológicos decorrentes da coarticulação. Antes da vogal / $\mathrm{u} /$, consoantes [-anteriores] pelo mesmo motivo, exceto com as palavras ['lulu], ['luta] e [lu'ta]. Nós optamos por essas vogais por estarem em regiões quânticas e serem menos suscetíveis a sofrerem processos fonológicos. As palavras estão discriminadas nos quadros 1 e 2 .

Quadro 1 - Palavras-alvo com consoantes e vogais iguais em sílabas pretônica e tônica.

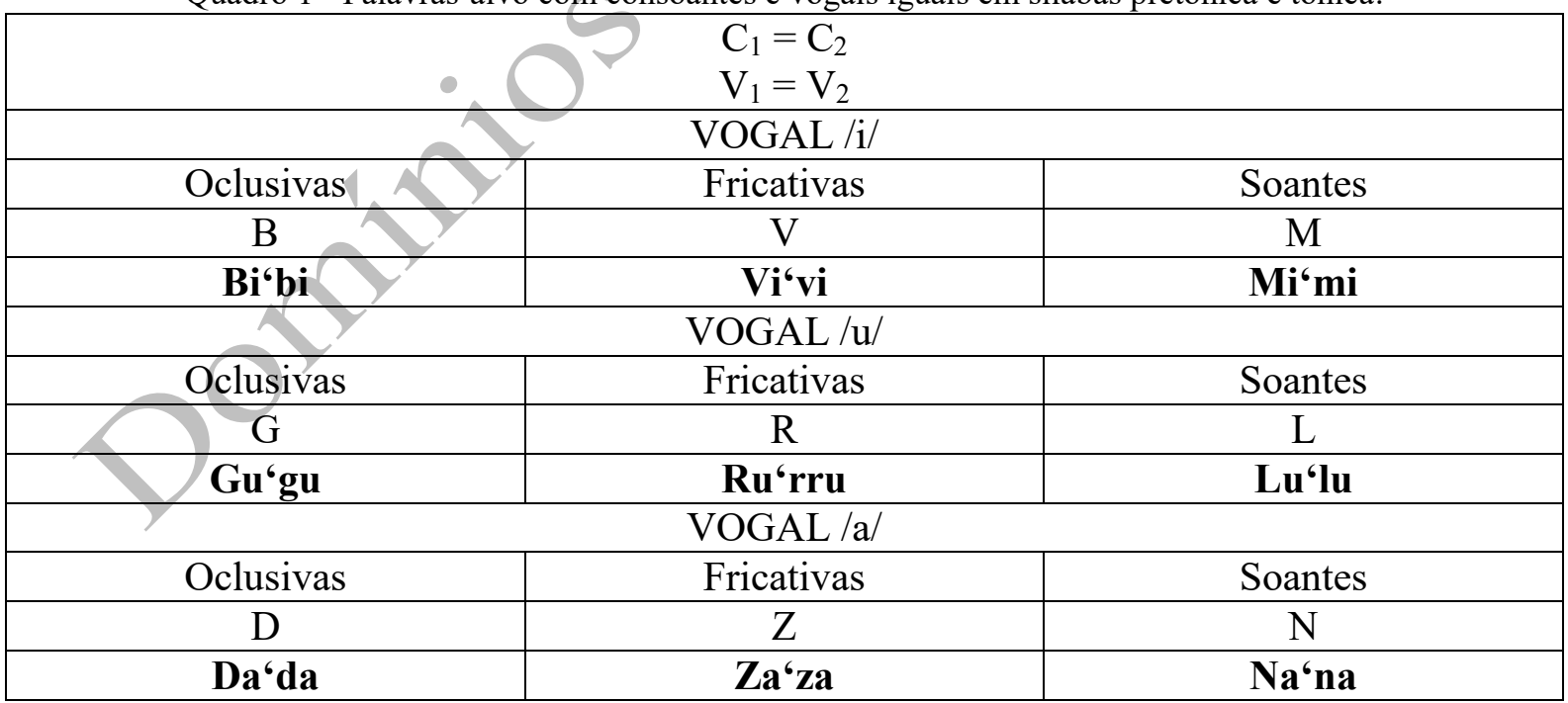

Fonte: Elaboração própria. 
Quadro 2 - Palavras-alvo com consoantes e vogais diferentes nas sílabas pretônica e tônica.

\begin{tabular}{|c|c|c|}
\hline \multicolumn{3}{|c|}{$\mathrm{C}_{1 \neq} \neq \mathrm{C}_{2}$} \\
$\mathrm{~V}_{1} \neq \mathrm{C}_{2}$ \\
\hline & VOGAL $/ \mathbf{i} /$ \\
\hline Oclusivas & Fricativas & Soantes \\
\hline B & V & M \\
\hline 'bica & 'vila & Mi'co \\
\hline Bi'ca & Vi'la & Soantes \\
\hline Oclusivas & VOGAL /u/ & L \\
\hline G & Fricativas & 'Luta \\
\hline 'Gula & R & Lu'ta \\
\hline Gu'la & 'Ruga & ' \\
\hline & Ru'ga & Soantes \\
\hline Oclusivas & VOGAL /a/ & N \\
\hline D & Fricativas & 'Nada \\
\hline Da'li & Z & Na'da \\
\hline Li'da & 'Zaga & Za'ga \\
\hline
\end{tabular}

Fonte: elaboração própria.

As palavras foram inseridas na frase veículo "Digo__ baixinho", com o objetivo de padronizar o contexto de produção.

\subsection{Gravações}

As gravações foram feitas por meio do programa Audacity, no Mac book pro, processador 2,4 GHz Intel Core i5, software OS X 10.9.4, com microfone interno com redução de ruído externo, a uma taxa de amostragem de $44.100 \mathrm{~Hz}$, do fabricante Apple Inc, em ambientes silenciosos, a fịm de evitar interferências do ambiente externo. As frases-veículo foram impressas e apresentadas aos informantes. Foram feitas cinco repetições de cada frase. As gravações foram realizadas nas cidades de origem dos sujeitos avaliados.

\subsection{Mensurações}

Foram mensurados, por meio do Software de análise acústica Praat (BOERSMAN; WEENICK, 2006), os valores de $\mathrm{F}_{0}$ das vogais pretônicas e tônicas em três pontos obtidos ao longo da realização da vogal: no início no meio e no final da mesma. Consideramos como ponto inicial, o primeiro pico regular da vogal, imediatamente depois da consoante; o ponto medial, o meio da vogal, localizado automaticamente pelo Praat, através do comando "control 0"; e o ponto final, último pico regular imediatamente antes da consoante, quando era o caso. Dessa 
forma, os três pontos - ponto inicial, ponto medial e ponto final - de obtenção dos valores da $\mathrm{F}_{0}$ ao longo da vogal foram obtidos como demonstrado na figura 1, indicados, respectivamente, como P1, P2 e P3.

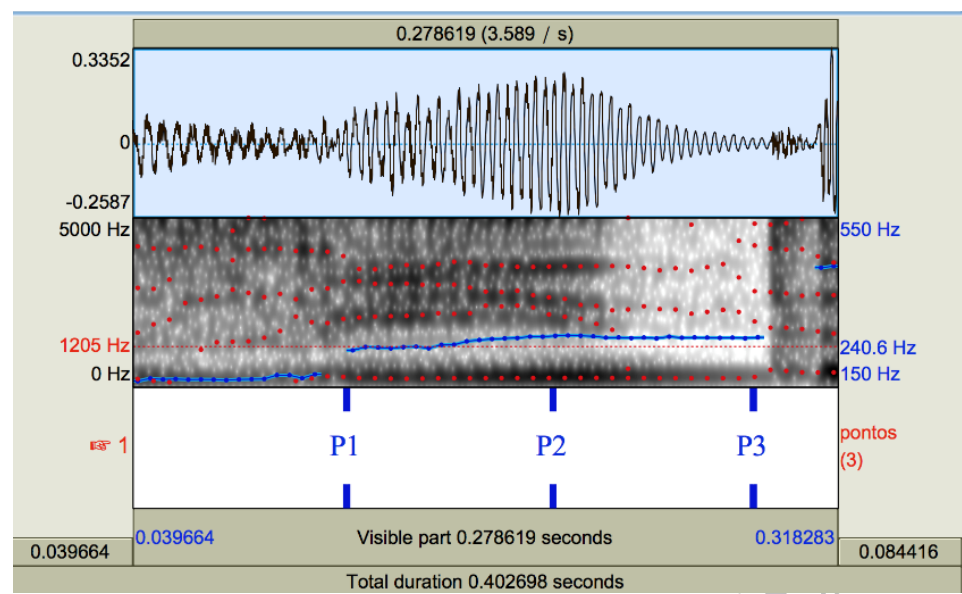

Figura 1- Forma de onda e espectrograma da vogal [i] com indicação dos três pontos de medida da $\mathrm{F}_{0}$ ( $\mathrm{P} 1$, início, P2, meio e P3, fim).

Fonte: elaboração própria.

Com esse procedimento metodológico fomos capazes de avaliar a $\mathrm{F}_{0}$ ao longo da produção da vogal e não somente analisá-la em um ponto específico.

\subsection{Análise estatística}

Para avaliar a distância e a proximidade dos falares de Salvador, Teófilo Otoni e Vitória da Conquista, no que se refere à $\mathrm{F}_{0}$, procedemos a análise multivariada discriminante, que é uma ferramenta estatística que permite ao pesquisador separar e discriminar os grupos de indivíduos ou objetos, a partir da determinação das funções discriminantes de Fischer, Y1 e Y2, que são duas vạriáveis adimensionais. Essas variáveis permitem melhor separação e discriminação entre os grupos que estão sendo analisados. A análise se dá a partir da geração de um diagrama que identifica os grupos e permite a visualização das separações e aproximações grupais (AYRES et al., 2007).

A análise discriminante permitiu comparar as medidas de $\mathrm{F}_{0}$ obtidas a partir da extração de valores em três pontos de cada uma das vogais, /a/, /i/ e /u/ (início, meio e fím) na sílaba pretônica e na sílaba tônica de cada uma das cinco repetições. Esse procedimento metodológico atenuou possíveis diferenças nos valores de $\mathrm{F}_{0}$ decorrentes de características fisiológicas dos sujeitos participantes dessa pesquisa. As medidas para cada uma dessas variáveis para as 
produções de Salvador constituíram o Grupo 1; Grupo 2, as produções de Teófilo Otoni e Grupo 3, as produções de Vitória da Conquista.

Os valores das variáveis são distribuídos a partir do cálculo das discriminantes de Fischer em um diagrama constituído por quatro quadrantes, aqui identificados como: Quadrante I: superior esquerdo; Quadrante II: superior direito; Quadrante III: inferior direito e Quadrante IV: inferior esquerdo, como esquematizado na figura 2.
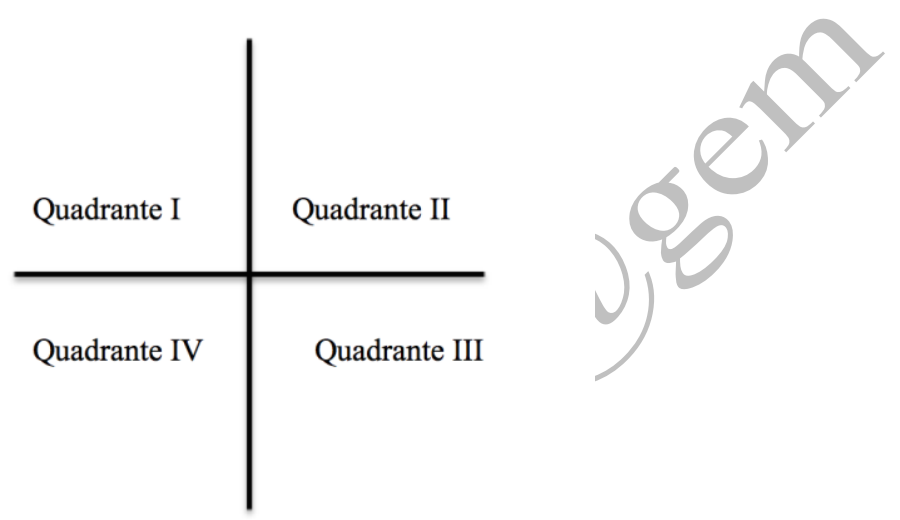

Figura 2 - representação esquemática da distribuição dos quatro quadrantes sobre os quais serão plotados os resultados da análise multivariada discriminante.

Fonte: elaboração própria.

Apresentada a metodologia por nós utilizada, passemos agora a examinar os resultados obtidos e as discussões deles provenientes.

\section{Resultados e discussões}

A frequência fundamental é a onda de menor valor de uma onda sonora harmônica e a variação de pitch é a indicação perceptual da variação contínua de valores altos e baixos da frequência fundamental (KENT; READ, 1992) e é um parâmetro robusto, como aqui discutido, na investigação sobre diferenças dialetais.

A Fo exerce um papel importante na língua, como a distinção entre consoantes surdas e sonoras e, obviamente na fala, como indicação de sussurro, murmúrio, etc. Aqui buscamos investigar se pessoas de cidades diferentes podem apresentar um padrão de $\mathrm{F}_{0}$ na sílaba que seja diferente entre cidades.

Nesta seção apresentamos os resultados obtidos na investigação sobre a relação entre os falares de Vitória da Conquista, Salvador e Teófilo Otoni no que se refere a configuração da $\mathrm{F}_{0}$ 
das vogais /a/, /i/ e /u/ tanto em sílaba tônica, quanto pretônica, produzida por sujeitos femininos e masculinos.

\subsection{A frequência fundamental das sílabas tônica e pretônica nucleadas pela vogal /a/ como marca dialetal}

Os gráficos 1, 2, 3 e 4 referem-se aos resultados da análise multivariada discriminante obtidos para o /a/ na posição tônica de sujeitos femininos; pretônica de sujeitos femininos; tônica de sujeitos masculinos e pretônica de sujeitos masculinos, respectivamente. Nesses e nos demais gráficos desta seção, encontraremos a disposição discriminante da $\mathrm{F}_{0}$ para as três cidades, sendo possível observar a relação entre elas. Nessa análise foram usados os valores médios da $\mathrm{F}_{0}$ resultantes da mensuração obtida em três pontos diferentes da vogal: no início, no meio e no fim. Assim, seremos capazes de avaliar o quanto a fala dessas três cidades distam-se ou aproximam-se no que se refere à $\mathrm{F}_{0}$ média de toda a vogal e seremos igualmente capazes de afirmar se esses lugares guardam entre si semelhanças ou diferenças.

A vogal /a/, para os sujeitos femininos, mostrou-nos ser uma vogal que pode ser realizada de forma diferente nas três cidades, por um lado, e não tão diferente assim por outro. Seu comportamento vai depender do tipo sílaba: tônica e átona, conforme os gráficos 1 e 2 .

Gráfico 1 - Análise multifatorial discriminante da $\mathrm{F}_{0}$ da vogal /a/ tônica produzida por sujeitos femininos de Salvador (Grupo 1), Teófilo Otoni (Grupo 2) e Vitória da Conquista (Grupo 3).

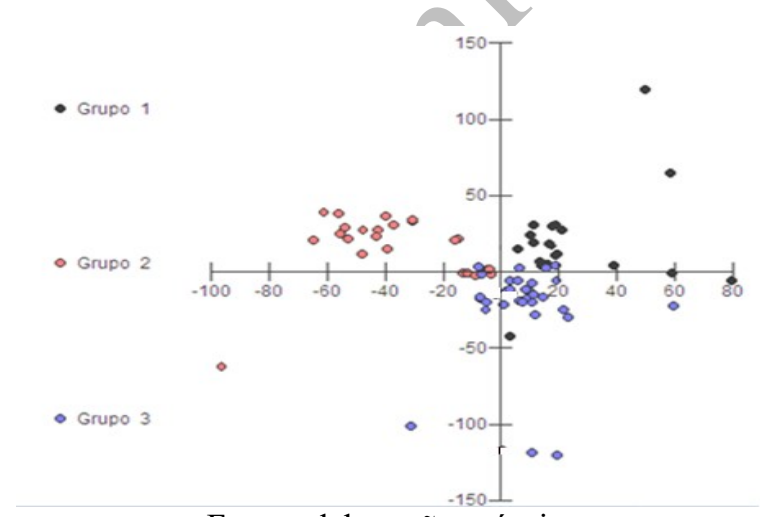

Fonte: elaboração própria.
Gráfico 2 - Análise multifatorial discriminante da $\mathrm{F}_{0}$ da vogal /a/ pretônica produzida por sujeitos femininos de Salvador (Grupo 1), Teófilo Otoni (Grupo 2) e Vitória da Conquista (Grupo 3).

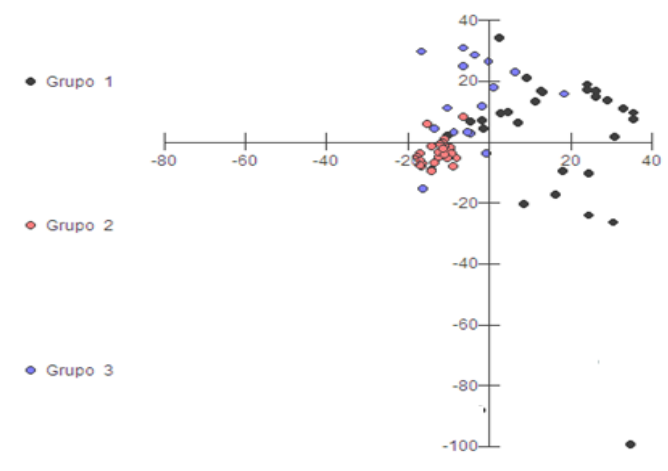

Fonte: elaboração própria.

A distribuição dos pontos, que representam os valores da $\mathrm{F}_{0}$, para os três grupos (Grupo 1, Salvador; Grupo 2, Teófilo Otoni e Grupo 3, Vitória da Conquista) ao longo dos gráficos nos dá uma dimensão de como essas três localidades se encontram em termos acústicos. 
Observando a localização dos pontos nos 4 quadrantes (I - superior esquerdo; IIsuperior direito; III- inferior direito e IV- inferior esquerdo), podemos afirmar, no que se refere à produção da vogal /a/ tônica, que Salvador (Grupo 1, em preto) e Teófilo Otoni (Grupo 2, em vermelho) encontram-se em planos opostos: Teófilo Otoni no quadrante I e Salvador no quadrante II.

A produção dos falantes conquistenses na sílaba tônica encontra-se majoritariamente no quadrante III, com alguns pontos dispersos nos quadrantes I e II, sobrepondo-se à produção das produções de Teófilo Otoni e Salvador, respectivamente.

Um cenário diferente se descortina na produção da vogal /a/ em sílaba pretônica: a produção dos conquistenses se concentra no quadrante I com algumas ocorrências nos quadrantes II, sobrepondo-se à produção dos soteropolitanos e não mais no quadrante III, como nas tônicas. A produção dos teófilo-otonenses, que se concentra no quadrante I nas tônicas, concentra-se, na pretônica, no quadrante IV, estendendo-se timidamente para o quadrante I, sobrepondo-se à produção conquistense. A distribuição da produção dos soteropolitanos atinge os quadrantes II e III, além de alcançar o quadrante I, com leve sobreposição com a produção conquistense.

Em suma, podemos afirmar que Salvador, Teófilo Otoni e Vitória da Conquista possuem marcas específicas de $\mathrm{F}_{0}$ para a vogal /a/, na sílaba tônica. Esse resultado acena para a possibilidade de se investigar, a partir de testes de percepção, se a $F_{0}$ pode ser parâmetro importante na distinção dialetal.

Para a sílaba pretônica, podemos sintetizar os dados da vogal /a/, afirmando que há proximidade entre os dados de Teófilo Otoni e Vitória da Conquista e Vitória da Conquista e Salvador. Apesar de não haver sobreposição entre as ocorrências de Teófilo Otoni e Salvador, podemos observar uma aproximação entre essas ocorrências no limite dos quadrantes I e IV (cf. gráfico 2). Diante disso, a vogal /a/ de sílaba pretônica pode não ser parâmetro razoável para distinguir falantes dessas três localidades. Essa separação pouco delimitada pode levar à indistinção dialetal dos falantes dessas cidades.

Enfim, no que se refere à vogal /a/ produzida por sujeitos femininos, podemos afirmar que as três localidades apresentam perfis diferentes especificamente na sílaba tônica, apesar de observarmos alguns pequenos pontos de contato entre Teófilo Otoni e Vitória da Conquista e Salvador e Vitória da Conquista, sendo nítida a distância entre Teófilo Otoni e Salvador. 
Esse mesmo padrão pode, de forma geral, ser encontrado na produção da vogal /a/ de sujeitos masculinos na sílaba tônica (cf. gráfico 3), uma vez que Teófilo Otoni e Salvador possuem suas ocorrências em quadrantes opostos.

Gráfico 3 - Análise multifatorial discriminante da $\mathrm{F}_{0}$ da vogal /a/ tônica produzida por sujeitos masculinos de Salvador (Grupo 1), Teófilo Otoni (Grupo 2 ) e Vitória da Conquista (Grupo 3).

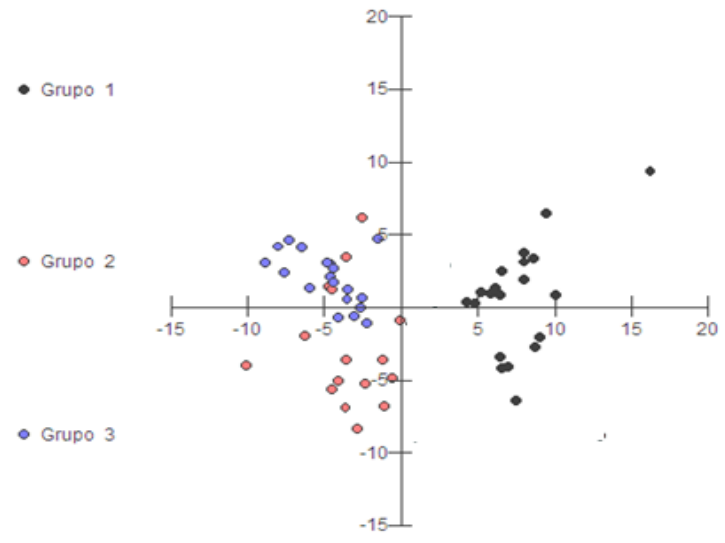

Fonte: elaboração própria.
Gráfico 4 - Análise multifatorial discriminante da $\mathrm{F}_{0}$ da vogal /a/ pretônica produzida por sujeitos masculinos de Salvador (Grupo 1), Teófilo Otoni (Grupo 2 ) e Vitória da Conquista (Grupo 3).

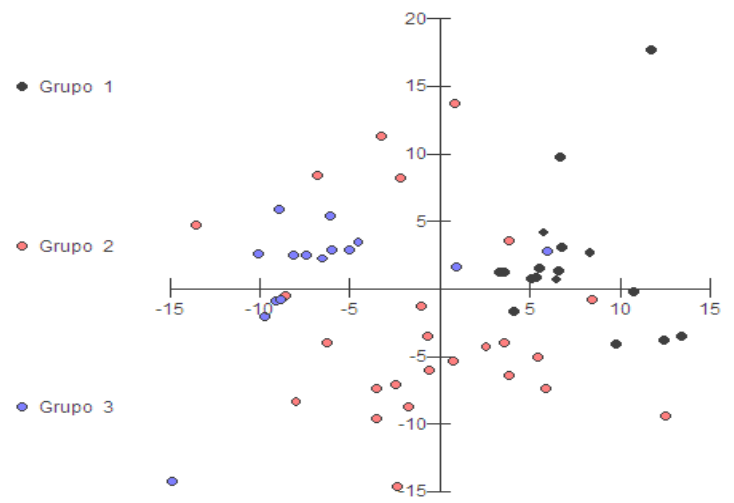

Fonte: elaboração própria.

Podemos encontrar, contudo, nos dados dos sujeitos masculinos, uma distribuição das ocorrências nos quadrantes com algumas diferenças se comparamos com os dados femininos. Diferentemente do que se observa para os sujeitos femininos, os sujeitos masculinos conquistenses só possuem produção no quadrante I, com algumas poucas ocorrências no quadrante IV, sobrepondo-se às ocorrências de Teófilo Otoni. As produções de Teófilo Otoni concentram-se no quadrante IV com algumas poucas ocorrências no quadrante I, onde se encontra a maioria das produções conquistenses.

Embora os dados femininos e masculinos apresentem algumas diferenças de distribuição da $\mathrm{F}_{0}$ entre as três cidades, o padrão geral de distribuição das ocorrências desse parâmetro para os sujeitos masculinos segue o dos sujeitos femininos. Como foi observado nos dados dos sujeitos femininos, as três localidades apresentam perfis diferentes da $\mathrm{F}_{0}$ na vogal /a/ de sílaba tônica, embora haja pontos de contato entre Teófilo Otoni e Vitória da Conquista. Teófilo Otoni e Salvador encontram-se distante no que se refere a esse parâmetro. Para os dados masculinos podemos observar ainda uma oposição entre Vitória da Conquista e Salvador na sílaba tônica. 
Como ocorre com os sujeitos femininos, a produção da vogal /a/ em sílaba pretônica por sujeitos masculinos também não constitui um parâmetro satisfatório para identificar os falantes das três cidades avaliadas (cf. gráfico 4). Não há delimitação dessas produções vocálicas, sendo possível encontrar ocorrências de Teófilo Otoni nos quadrantes I, II, III e IV, e produções conquistenses dispersas nos quadrantes I, II e III. Vale ressaltar que, apesar de não verificarmos limites precisos das produções dos sujeitos de Teófilo Otoni e de Vitória da Conquista, as produções dos soteropolitanos estão circunscritas ao quadrante II.

\subsection{A frequência fundamental das sílabas tônica e pretônica nucleadas pelas vogais /i/ e /u/ como marca dialetal}

Diante das constatações e reflexões até aqui desenvolvidas para a vogal /a/, resta-nos perguntar como será a distribuição da frequência fundamental nas três cidades investigadas no que se refere às vogais altas $/ \mathrm{i}, \mathrm{u} / . \mathrm{A} \mathrm{F}_{0}$ sobre essas vogais pode delimitar dialetos, como o faz a vogal /a/ em sílaba tônica? A resposta a essa pergunta pode ser obtida a partir das análises dos dados dispostos nos gráficos de 5 a 8 .

Um olhar geral lançado sobre esses gráficos permite afirmar que estas duas vogais, /i, $\mathrm{u} /$, apresentam a distribuição dos valores de $\mathrm{F}_{0}$ entre as localidades investigadas muito similar àquela encontrada para a vogal /a/.

Avaliando a análise multifatorial discriminante das produções da vogal /i/ em sílaba tônica de sujeitos femininos, podemos verificar que os três grupos podem ser delimitados em três zonas relativamente bem delimitadas. As ocorrências de Teófilo Otoni se encontram distribuídas entre os quadrantes I e IV; as de Salvador encontram-se centradas no quadrante II e Vitória da Conquista majoritariamente no quadrante III, com algumas poucas ocorrências no quadrante IV, coocorrendo com produções de Teófilo Otoni e uma única ocorrência no quadrante II, próxima das ocorrências de Salvador (ver gráfico 5). 
Gráfico 5 - Análise multifatorial discriminante da $\mathrm{F}_{0}$ da vogal /i/ tônica produzida por sujeitos femininos de Salvador (Grupo 1), Teófilo Otoni (Grupo 2) e Vitória da Conquista (Grupo 3).

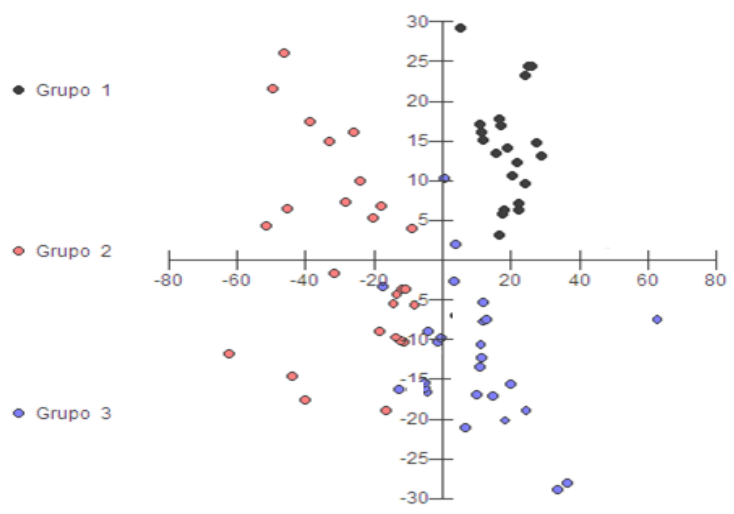

Fonte: elaboração própria.
Gráfico 6 - Análise multifatorial discriminante da $\mathrm{F}_{0}$ da vogal /i/ pretônica produzida por sujeitos femininos de Salvador (Grupo 1), Teófilo Otoni (Grupo 2) e Vitória da Conquista (Grupo 3).

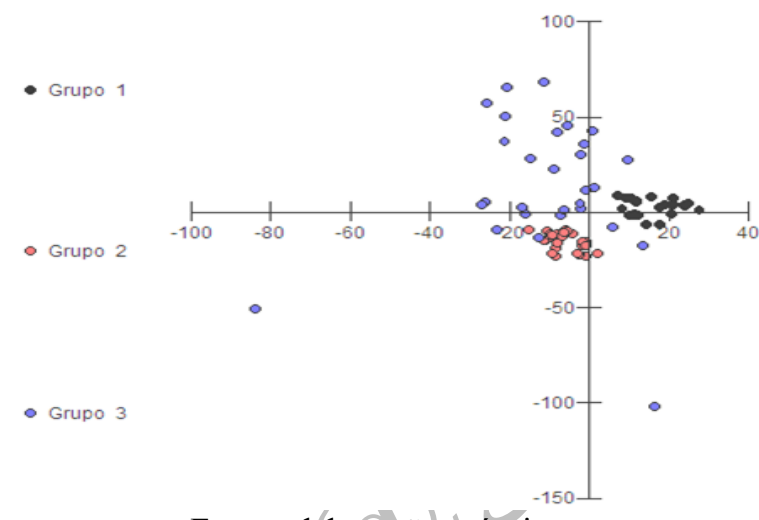

Fonte: elaboração própria

Diante dessa distribuição, podemos afirmar que, em sílaba tônica, Teófilo Otoni e Salvador e Vitória da Conquista e Salvador encontram-se distantes sem qualquer ponto de interseção, e Vitória da Conquista e Teófilo Otoni podem ter traços que as aproximam, mesmo que levemente. A única ocorrência de produção de Vitória da Conquista no quadrante no qual predominam as produções de Salvador não é suficiente para afirmarmos que haja um ponto de contato substancial entre esses dois falares nesse contexto.

Na sílaba pretônica, de acordo com o gráfico 6, a vogal /i/ produzida por conquistenses encontra-se preferencialmente no quadrante I, havendo, contudo, algumas poucas ocorrências no quadrante II e III, nos quais estão concentradas as ocorrências soteropolitanas, além de encontrarmos algumas poucas ocorrências também no quadrante IV, no qual estão as ocorrências de Teófilo Otoni, as quais ocorrem exclusivamente nesse quadrante, mais próximas do zero do que na sílaba tônica.

Ainda observando as zonas de distribuição das produções do /i/ no gráfico 6, podemos verificar que as produções do /i/ dos três grupos giram em torno do ponto de interseção dos eixos x e y: Salvador e Teófilo Otoni com maior aglomeração nesse ponto e Vitória da Conquista com alguma.

Esse dado lança-nos pistas para a possibilidade de, na sílaba pretônica, a vogal /i/, à semelhança da vogal /a/, não ser exatamente um parâmetro diferenciador de dialetos. O limite separador desses três dialetos, para a vogal /i/, na sílaba pretônica, é pequeno, o que abre margem para pouca diferenciação entre eles. 
$\mathrm{O}$ quadro de distribuição da $\mathrm{F}_{0}$ da vogal /i/ produzida por sujeitos masculinos em quase nada se difere dos quadros de distribuição da frequência fundamental delineados até aqui: na sílaba tônica, observamos limites melhor delineados entre os três grupos e frágil delimitação deles na sílaba pretônica, conforme dados dos gráficos 7 e 8 , respectivamente.
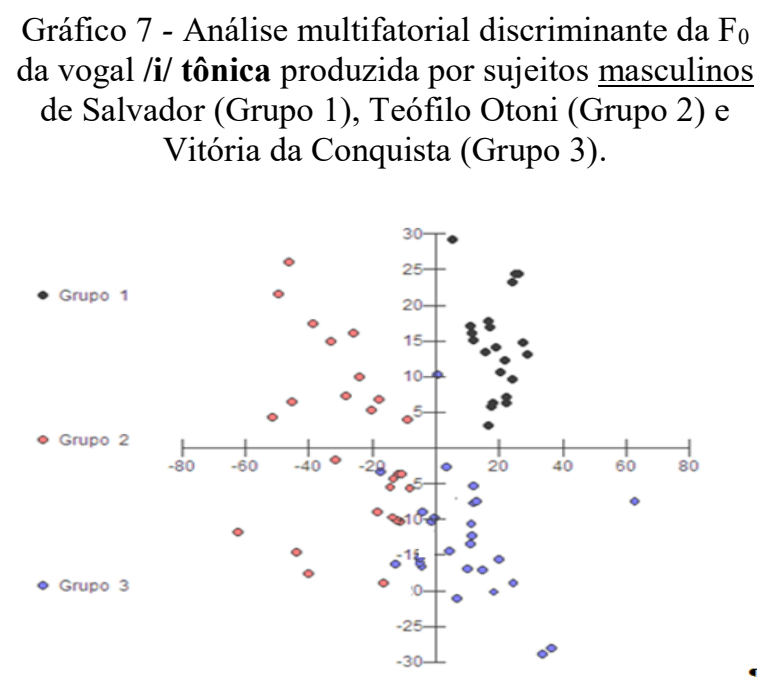

Fonte: elaboração própria.
Gráfico 8 - Análise multifatorial discriminante da F0 da vogal /i/ pretônica produzida por sujeitos masculinos de Salvador (Grupo 1), Teófilo Otoni (Grupo 2) e Vitória da Conquista (Grupo 3).

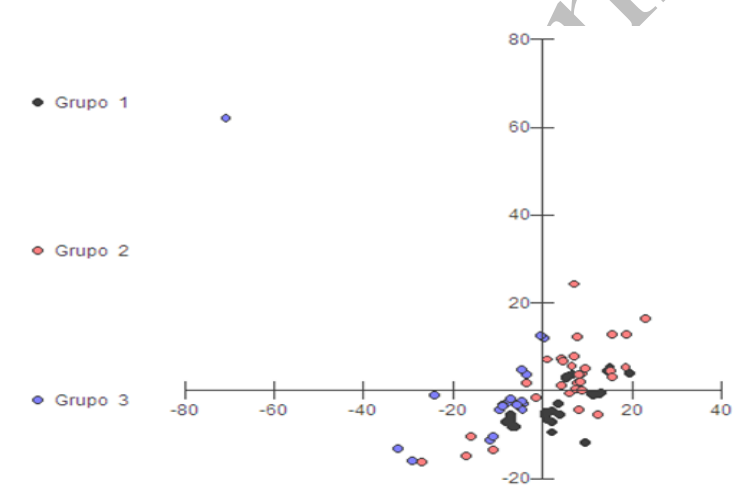

Fonte: elaboração própria.

Assim, temos, novamente, as produções soteropolitanas concentradas exclusivamente no quadrante II; produções teófilo-otonenses distribuídas entre os quadrantes I e IV, sem qualquer interseção com as produções de Salvador, e as produções conquistenses, na sua maioria, localizadas no quadrante HI com alguns pontos de interseção com as produções de Teófilo Otoni no quadrante TV, sem qualquer interseção com as produções de Salvador.

É possível, dessa forma, visualizar, de forma bem clara, as zonas de distribuições das produções da vogal/i/ em sílaba tônica dos falantes de cada uma das cidades, situação bem diferente daquela encontra para a sílaba pretônica (cf. gráfico 8), como tem sido a tendência.

$\mathrm{Na}$ distribuição dos valores da $\mathrm{F}_{0}$ da vogal /i/ em sílaba pretônica, para sujeitos masculinos, o quadrante I comporta somente algumas poucas produções de conquistenses, produções essas que se concentram no quadrante IV que recebe também algumas ocorrências de Teófilo Otoni cujo maior montante de ocorrências encontra-se no quadrante II e algumas outras poucas no quadrante III (cf. gráfico 8).

Ainda de acordo com os dados do gráfico 8, podemos verificar que as produções dos soteropolitanos masculinos para a vogal átona podem ser encontradas em três dos quatro quadrantes: algumas ocorrências no quadrante II e III, juntamente com as ocorrências de 
produções de Teófilo Otoni, e no quadrante IV, em coocorrência com produções de conquistenses e de teófilo-otonenses.

É, pois, com a distribuição que ora apresentamos, impossível delimitar o falar de Salvador, Teófilo Otoni e Vitória da Conquista, quando se tem de considerar a vogal /i/ em sílaba pretônica produzida por sujeitos masculinos; o que não é, vale ressaltar, diferente do que foi também encontrado para os sujeitos femininos.

Passando, finalmente, para a avaliação da $\mathrm{F}_{0}$ de sílabas tônicas e pretônicas com /u/ produzida por sujeitos femininos e masculinos (gráficos 9, 10, 11 e 12), encontramos uma distribuição dessa variável bem próxima ao que até agora encontramos para as demais vogais, exceto para/u/ pretônica produzida por sujeitos femininos, que, como veremos, mostrou possuir da $\mathrm{F}_{0}$ bem delimitada pelo menos para Salvador e Teófilo Otoni.

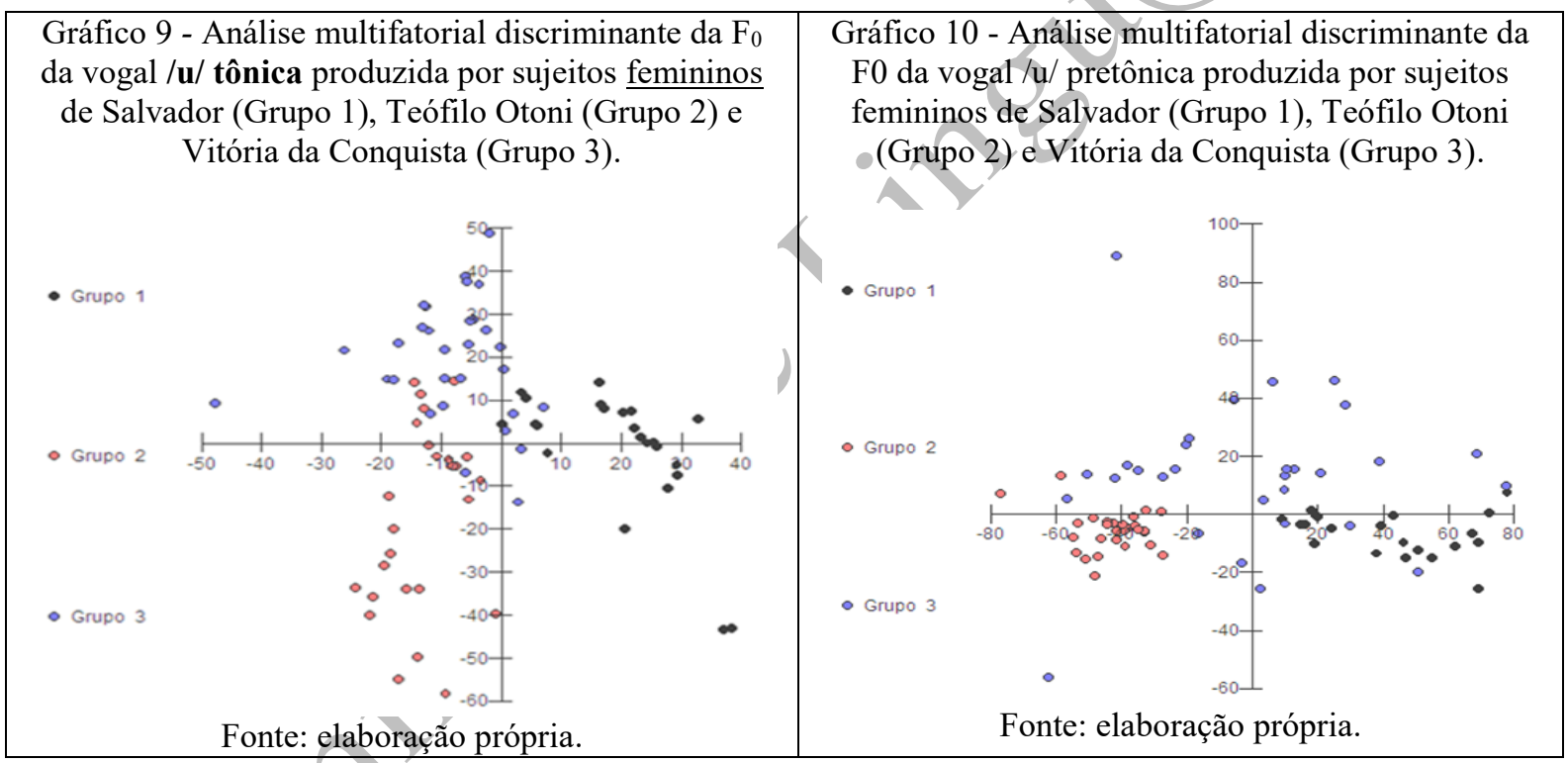

Verificamos nos dados encontrados no gráfico 9 grande quantidade de ocorrências das produções conquistenses no quadrante I e algumas poucas nos quadrantes II e IV, coocorrendo, respectivamente, com dados de Salvador, que se distribuem entre os quadrantes II e III, e de Teófilo Otoni, cujas ocorrências encontram-se majoritariamente no quadrante IV, podendo ser observadas algumas outras no quadrante I.

Na sílaba tônica com vogal /u/ produzida por sujeitos femininos, à semelhança do que já observamos anteriormente, as $\mathrm{F}_{0}$ médias possuem zonas de distribuição para as três cidades avaliadas bem delimitadas, observando pequena sobreposição entre Vitória da Conquista e Teófilo Otoni e Vitória da Conquista e Salvador, bem como ausência de sobreposição entre 
ocorrências de Teófilo Otoni e Salvador. As produções dessas duas cidades encontram-se distantes entre si.

Em sílaba pretônica, a vogal /u/ produzida por sujeitos femininos apresentou distribuição da $F_{0}$ diferente da observada para as vogais /a/ e /i/, pois podemos encontrar as produções das três cidades em zonas mais delimitadas do que se espera para as pretônicas, sem confluência entre as produções de Salvador e Teófilo ou proximidades entre as duas, à semelhança do que encontramos para /a/ e /i/ tônicos.

Assim, temos as produções de Vitória da Conquista bem concentradas nos quadrantes I e II com algumas poucas ocorrências no quadrante III, junto com Salvador, e ainda algumas outras poucas no quadrante IV, junto com Teófilo Otoni. Salvador e Teófilo Otoni possuem suas produções localizadas majoritariamente nos quadrantes III e IV, respectivamente, com produções mínimas no quadrante superior (I para Teófilo Otoni e II para Salvador), juntamente com ocorrências de Vitória da Conquista.

Apesar de pequenas sobreposições entre as zonas de ocorrências, a vogal /u/ de sílaba pretônica de sujeitos femininos pode contribuir para a identificação de falantes como pertencentes a essa ou aquela localidade.

A vogal / $\mathrm{u} /$ produzida por sujeitos masculinos apresenta distribuição da $\mathrm{F}_{0}$ diferenciada em sílaba tônica e pretônica, como ocorre com as demais vogais /a/ e /i/ nesses contextos de tonicidade, como podemos verificar, respectivamente, nos gráficos 11 e 12 .

Gráfico 11 - Análise multifatorial discriminante da F0 da vogal /u/ tônica produzida por sujeitos masculinos de Salvador (Grupo 1), Teófilo Otoni

(Grupo 2) e Vitória da Conquista (Grupo 3).

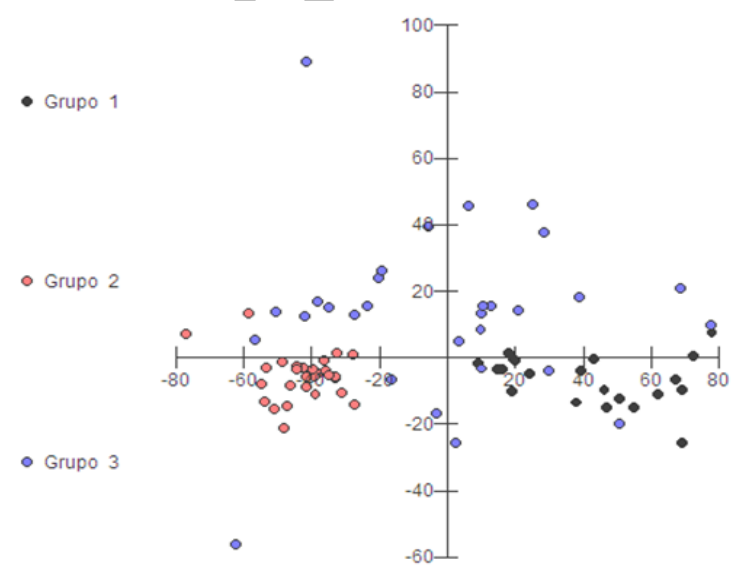

Fonte: elaboração própria.
Gráfico 12 - Análise multifatorial discriminante da F0 da vogal /u/ pretônica produzida por sujeitos masculinos de Salvador (Grupo 1), Teófilo Otoni

(Grupo 2) e Vitória da Conquista (Grupo 3).

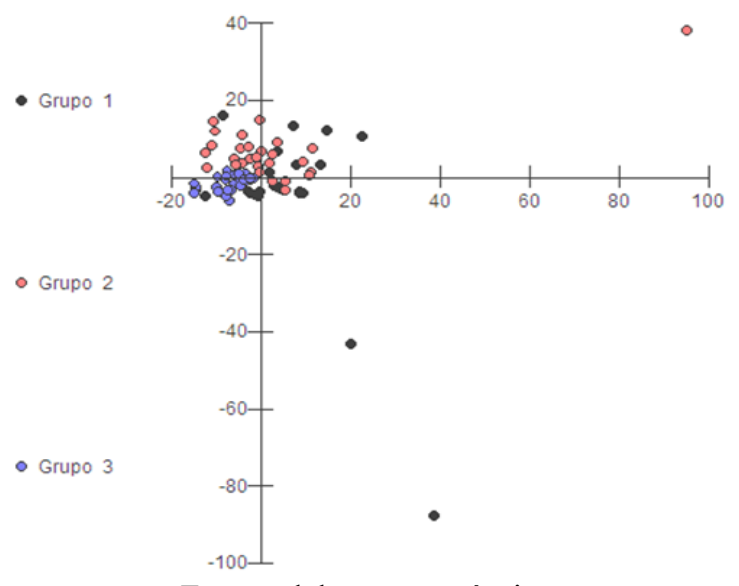

Fonte: elaboração própria. 
As produções soteropolitanas encontram-se no quadrante III e as teófilo-otonenses no quadrante IV, sem qualquer ponto de contato entre elas. A produção conquistense distribui-se majoritariamente entre os quadrantes I e II e timidamente entre os quadrantes III e IV (cf. gráfico 11).

Um cenário diferente é o encontrado para a vogal /u/ em sílaba pretônica (cf. gráfico 12), que se caracteriza por uma concentração das ocorrências das três localidades no ponto de interseção dos eixos x e y. Não há qualquer distância entre as zonas de produção dessa vogal, nesse contexto, o que nos sugere que há uma semelhança de produção dessa vogal na produção vocálica dos falantes dessas cidades, nesse tipo de sílaba.

Após avaliarmos as médias de $\mathrm{F}_{0}$ das vogais /a/, /i/ e /u/ em sílabas tônica e pretônica, somos capazes de determinar em que medida esse parâmetro acústico pode contribuir para a identidade dialetal.

Nossas análises permitem afirmar que há uma diferença do comportamento da $\mathrm{F}_{0}$ nas vogais tônicas /a,i,u/ dessas três cidades. Nossas análises permitem também afirmar, ainda com relação a esse tipo silábico, que, de fato, não há nenhuma semelhança nesse parâmetro acústico nos falares de sujeitos nativos de Salvador e de Teófilo Otoni. Falantes de Vitória da Conquista, por sua vez, possuem uma produção bem característica, mas com alguns pontos de contatos com Salvador e Teófilo Otoni.

Os nossos resultados concordam com os resultados encontrados por Cunha (2000) para os dialetos de São Paulo e Rio de Janeiro. Vitória da Conquista, à semelhança de São Paulo e Rio de Janeiro, possui um padrão acústico que evidencia certa influência de outros falares. São Paulo e Rio de Janeiro apresentaram padrões prosódicos semelhantes aos das cidades nordestinas e gaúchas ao mesmo tempo. Esse resultado seria consequência da grande concentração de diferentes falares nessas duas cidades? É possível que sim. Da mesma forma, Vitória da Conquista, que recebe cidadãos de vários outras cidades baianas e mineiras pode possuir um padrão de $\mathrm{F}_{0}$ que esteja sofrendo influência desses diferentes falares.

O dado encontrado para Vitória da Conquista talvez possa ser explicado pelo fato de essa cidade, dada à proximidade geográfica, ter uma afinidade grande com Teófilo Otoni, havendo grande contato entre os moradores das duas cidades. Por outro lado, Vitória da Conquista, apesar da distância geográfica que se encontra da capital do estado, Salvador, mantém estreito contato com a metrópole. Conquistenses com frequência vão estudar e trabalhar em Salvador, da mesma forma que há muitos soteropolitanos vivendo em Vitória da 
Conquista,. Assim, é possível que os falantes de Vitória da Conquista possuam uma forma de dizer que permita encontrar traços de influência de Teófilo Otoni e de Salvador.

Podemos afirmar que a relação existente entre os falantes nativos de Vitória da Conquista e Teófilo Otoni e de Vitória da Conquista e Salvador foi expressa na análise discriminante da $\mathrm{F}_{0}$. Nas variedades linguísticas estudas, esse parâmetro acústico pode ajudar a compreender as demarcações dialetais, assim como foi verificado para algumas variedades do inglês americano (JACEWICZ; FOX, 2015) e de certa maneira para os dialetos catarinenses, como investigado por Sosa, Nunes e Seara (2013).

Dados os resultados encontrados que mostram que esses falares possuem padrão de $\mathrm{F}_{0}$ delineado em dois grandes grupos (Vitória da Conquista/ Teófilo Otoni x Salvador), podemos inferir que esse parâmetro ao ser processado pelo ouvinte, pode despertar o sentimento de pertencimento à comunidade de fala de Vitória da Conquista, por exemplo; isto porque a $\mathrm{F}_{0}$ pode atuar significativamente na percepção e reconhecimento de dialetos (PERES, 2011), além, obviamente, da ocorrência das vogais médias abertas em sílabas pretônicas muito comuns nesse dialeto e do padrão de curva de $\mathrm{F}_{0}$ das vogais médias abertas que não apresenta diferença entre as sílabas tônicas e pretônicas, o que é pouco esperado, pois sílaba tônicas tendem a ter maiores valores de $\mathrm{F}_{0}$ (OLIVEIRA; RIBEIRO; PACHECO, 2007, PACHECO; OLIVEIRA; RIBEIRO, 2013).

E o que dizer dos demais parâmetros acústicos prosódicos, intensidade e duração, que são outros dois parâmetros importantes na análise acústica prosódica? Trabalhos futuros responderão a essa a pergunta, para a qual temos a hipótese de que, a duração, a intensidade somada a $\mathrm{F}_{0}$ contribuem simultaneamente para delimitação desses falares.

\section{Considerações finais}

Neste artigo, investigamos o quanto os falares de Vitória da Conquista, Salvador e Teófilo Otoni se distanciam, comparando-os a partir da avaliação de $\mathrm{F}_{0}$ das vogais /a/, /i/ e /u/ de sílabas tônicas e pretônicas.

Por outro lado, Vitória da Conquista, uma cidade baiana com modos de mineiro, possui um falar baiano-mineiro. A produção vocálica conquistense, apesar de possuir uma delimitação própria, pode igualmente estender-se para um padrão mineiro ou baiano.

Nossos resultados mostram que as diferenças dialetais podem estar para além das vogais médias pretônicas, que podem sofrer abaixamento ou alteamento, como tem sido 
tradicionalmente descrito na literatura. As outras vogais do sistema fonológico, na sílaba tônica ou na pretônica podem ser coparticipantes de delimitação dialetal.

Diante disso, nosso trabalho descortina novas perguntas para trabalhos futuros, tais como: qual o papel da intensidade e da duração na delimitação dialetal?; cidades contíguas possuem falares contíguos, como uma espécie de empatia dialetal?; qual o alcance dessa "empatia", caso ela exista?; as mesorregiões, além das afinidades econômicas e sociais podem ter afinidades no seu modo de falar?.

Assim, nosso trabalho não se esgota por aqui. Temos ciência de que trouxemos uma pequena contribuição para os estudos linguísticos, mas muito ainda deve ser feito para uma compreensão maior do falar dos brasileiros.

\section{Referências bibliográficas}

ATKINSON, K. Language identification from non-segmental cues. Working Papers in Phonetics (UCLA), v. 10, p. 85-89, 1968.

AYRES, M.; AYRES JÚNIOR, M.; AYRES, D. L.; SANTOS, A. A. 2007. BIOESTAT Aplicações estatísticas nas áreas das ciências bio-médicas. Ong Mamiraua. Belém: Ong Mamiraua; 2007.

BISOL, L. Harmonização vocálica: uma regra variável. Rio de Janeiro, UFRJ, 1981. Tese de Doutorado.

BOERSMA, P.; WEENINK, D. Praat: doing phonetics by computer. (Version 5.1.43) [Programa de computador]. 2006. Disponível em http://www.praat.org/.

BONTE, R. Can you identify a language by its prosody? Dissertação (Mestrado) s.f. 1975. University of California, 1975.

BORTONI, S. et al. Um estudo preliminar do [e] pretônico. Cadernos de estudos lingüísticos, v. 20, 75-90, 1991.

CARDOSO, S. A. L. M.; MOTA, J. A., O atlas linguístico do Brasil (uma descrição do português brasileiro do Oiapoque ao Chuí. In: FONSECA-SILVA; PACHECO, V. LESSADE-OLIVEIRA , A. S. C. (Orgs.) Em torno da língua(gem): questões de análises. Vitória da Conquista: Edições Uesb, p. 139-159, 2007.

CELIA, G. F. Variação das vogais médias pretônicas no português de Nova Venécia (ES). (Dissertação de Mestrado) Campinas, UNICAMP, 2004. 
CLOPPER, C. G.; PISONI, D. B., Perception of dialect variation. In: PISONI, D. B.; REMEZ, R. E. (EDS.) The handbook of speech perception. Oxford: Blackwell Publishing, 2005. p. 313-337. crossref http://dx.doi.org/10.1002/9780470757024.ch13

COLOMARCO, M. Aspectos prosódicos do corpus do projeto ALiB: o padrão interrogativo na fala baiana e carioca. In: SANTOS, D. V. (org.) inicia - Revista da Graduação em Letras da UFRJ. Rio de Janeiro. Ed. Faculdade de Letras/URFJ, 2005, pp. 35-43

CRANDAL, J. B. The sounds of speech. Bell Sysy. Tech J., v. 4, p. 586-626, 1925.

CRUZ, R. et al. As vogais médias pretônicas no português falado nas ilhas de Belém (PA). In: . ARAGÃO, M. do S. (org.). Estudos em fonética e fonologia no Brasil. João Pessoa: GT Fonética e Fonologia / ANPOLL, 2008.

CUNHA, C. Entoação Regional no Português do Brasil. 2000. S.f Tese ( Doutorado) Faculdade de Letras, UFRJ, Rio de Janeiro.

GUIMARÃES, E. D. A variação entoacional da ilha de Mosqueiro: contribuições para a formação do Atlas Prosódico Multimídia do Português do Norte do Brasil (AMPER - NORTE). Dissertação (Mestrado). 2013. 143f. Instituto de Letras e Comunicação, Universidade Federal do Pará.

IBGE. População brasileira: Dados das pesquisas do Censo/2014. Disponível em: http://www.ibge.gov.br/censo2010/dados_divulgados/index.php.

JACEWICZ, E.; FOX, R. A. I Intrinsic fundamental frequency of vowels is moderated by regional dialect. The Journal of the Acoustical Society of America, v. 138, n. 4, p. 405-410, 2015.

KAILER, D. A. Alçamento da vogal pretônica /o/ em duas regiões paranaenses. SIGNUM: Estud. Ling., Londrina, n. 15/1, p. 201-221, jun. 2012. Disponível em: http://www.uel.br/revistas/uel/index.php/signum/article/view/11668/11175.

KENT, R. D.; READ, C. The acoustic analysis of speech. 2. ed. Cambridge: Singular, 1992.

LEE, S. H.; OLIVEIRA, M. A. de. Variação Inter- e Intra-Dialetal no Português Brasileiro: Um Problema para a Teoria Fonológica. In: . OLIVEIRA, D. da H.; COLLISCHONN, G. (Org.). Teoria Linguística: fonologia e outros temas. João Pessoa, 2003. p. 67-91.

LEHISTE, I.; PETERSON, G. Some basic considerations in the analysis of intonation. The Journal of the Acoustical Society of America, v. 33, p. 419-425, 1961. crossref http://dx.doi.org/10.1121/1.1908681

LIRA, Z. A entoação modal em cinco falares do nordeste brasileiro. 2009. s.f. Tese (Doutorado) - Centro de Ciências Humanas, Letras e Artes, Universidade Federal da Paraíba, João Pessoa. 
MAIDMENT, J. Voice fundamental frequency characteristics as language differentiators. Speech and Hearing Working in Progress, v. 16, 1976. p. 74-93.

NASCENTES, A. O linguajar carioca. Rio de Janeiro: Simões, 1953.

NINA, T. Aspectos da variação fonético-fonológica na fala de Belém. 1991. 216f. Tese (Doutorado em Língua Portuguesa) - Faculdade de Letras, Universidade Federal do Rio de Janeiro, Rio de Janeiro, 1991.

OHALA, J. J.; GILBERT, J. B. Listener's ability to identify languages from their prosody. Report of the Phonology Laboratory, v. 2, 1978. p. 126-132.

OHALA, J.J.; EUKEL, B. W. Explaining the intrinsic pitch of vowels. In: Channon, R.; Shockey, L. (eds.) In honor of Ilse Lehiste. Dordrecht: Foris, 1987. p. 207-215. crossref http://dx.doi.org/10.1515/9783110886078.207

OLIVEIRA, J. S. N. Análise acústico-perceptual das frases exclamativas e interrogativas realizadas por falantes de Vitória da Conquista/Ba. 2014. 79 p. Dissertação (Mestrado em Linguística). Universidade Estadual do Sudoeste da Bahia, Vitória da Conquista, 2014.

OLIVEIRA, J. S. N.; RIBEIRO, P. J.; PACHECO, V. Realização das vogais médias abertas no dialeto de Vitória da Conquista/BA. In: FONSECA-SILVA, M.C.; PACHECO, V. SILVA, E.G. (Org.). Pesquisas em Estudos da Linguagem III, Vitória da Conquista, v. 3, n.1, 2007. p. 67-74.

PACHECO, V.; OLIVEIRA, M.; RIBEIRO, P. de J. Em busca da melodia nordestina: as vogais médias pretônicas de um dialeto baiano. Linguística / Vol. 29 (1), junho 2013: 165-187. Disponível em: http://www.scielo.edu.uy/pdf/ling/v29n1/v29n1a08.pdf. Acesso em outubro de 2014.

PERES, D. O. O papel da prosódia na identificação das variedades regionais do português brasileiro. Dissertação (Mestrado). 151 f. 2011. Faculdade de Ciências Humanas. Universidade de São Paulo. 2011.

PETERSON, G. E. BARNEY, H.L. Control methods used in a study of the vowels. The Journal of the Acoustical Society of America, v. 24, 1952. p. 175-184.

SEARA, I. C. REBOLLO-COUTO, L. Entoação de frases declarativas e interrogativas no falar fluminense e catarinense. Congresso Internacional de la ALFAL, 16, 2011, Alcalá de Henares (Espanha). Actas.... Alcalá de Henares (Espanha): Universidade de Alcalá, 2011. p.4203-4208.

SILVA, J. C. B.; CUNHA, C.S. Caracterização prosódica dos falares brasileiros: a questão total em Recife, Rio de Janeiro e Florianóplis. Antares, v 3, n. 6, 2011. p. 282-294.

SOSA, J. M.; NUNES, G. V. SEARA, I. C. Variação prosódica das sentenças interrogativas totais no falar catarinense: um estudo experimental. Leitura, n. 52, 2013. p. 139-163. 
van BEZOOIJEN, R.; GOOSKENS, C. Identification of language varieties: the contribuitin of differente linguistic levels. Journal of Language and Social Psychology, v. 18, , 1999. p. 3148.

VIEGAS, M. C. Alçamento de vogais médias pretônicas: uma abordagem sociolinguística. Dissertação (Mestrado) 1987. s.f. Belo Horizonte, UFMG, 1987.

VOGELY, A. N.; HORA, D. Harmonia Vocálica no dialeto recifense. Organon, v. 28, n.54, 2013. p. 63-81.

WHALEN, D. H.; LEVITT, A. G. The universality of intrinsic $\mathrm{F}_{0}$ of vowels. Journal of Phonetics, v. 23, 1995. p. 349-366. crossref http://dx.doi.org/10.1016/S0095-4470(95)801650

ZENDRON DA CUNHA, K. Sentenças exclamativas do português brasileiro: padrão entoacional e sintaxe. Dissertação (Mestrado em Letras). Curitiba: Universidade Federal do Paraná, 2012 